\title{
Tourism development factor of communities
}

\author{
Manuela Liliana MUREȘAN \\ The Bucharest University of Economic Studies, Bucharest, Romania \\ manuela.muresan@stud.ase.ro \\ Puiu NISTOREANU \\ The Bucharest University of Economic Studies, Bucharest, Romania \\ puiu.nistoreanu@com.ase.ro
}

\begin{abstract}
Tourism has undoubtedly become a factor of economic and social development for everyone in contemporary society. What seems clear is that tourism growth, with the ultimate goal of increasing the socioeconomic level, is a chronological process that requires a certain amount of time before the desired results begin to be observed. Tourism in Romania is an activity linked to the cultural world and natural heritage, as well as the traditions and customs specific to each historical regions of the country. This research makes an analysis of the flow of visitors in Romania, but also an analysis of statistical data provided by the National Statistics Institute of Romania (in the range of 2013 - 2016) with regards to the departures of the Romanian population abroad. We were interested to see what who visits us and what geographical areas they are interested in, and what this means, but especially if this tourist flow analyzed for a period of four years has an impact on the development of the community. The data show that the largest number of arrivals in our country comes from our neighbors, so a tourism promotion strategy aimed at the neighboring markets would be an important factor for the development of tourism communities, all the more so with as are the countries whose main industry generating economic profit is tourism. A long-term national policy of investment and promotion of the destination Romania at international level is necessary, especially since the data obtained clearly tells us that the interest in the Romanian tourism is increasing and this fact leads to the development of the community where it is being developed.
\end{abstract}

Keywords: tourism, community, economic development, tourism circulation, sustainability.

\section{Introduction}

Millennium twenty-one is marked by the change in all areas of action, and this is also reflected the lives of the communities. Year after year, technology is innovating and changing our lives in a fast way, which to which we must adapt as human beings and by default as a society. Between the economic activities with the fast development factor, the tourism sector has been marked obviously by this trend. If, after a few hundreds of years, people traveled during the days or even weeks from one to another of the earthly globe, now technology development helped to carry the continents within a few hours. Communication is an important vector of changes in the present life - we evolved from sending the pigeon to communicating in real time, instantly, anywhere on the globe and in equal measure in the cosmic space. The development of science in all areas of the social and economic activity, lead seized to ease the life of the communities of which we are part. The specialists in the fields of technological development want a world in continuous 
development, but through sustainable methods. (European Commission 2020, 2010)

Tourism activity is a competitive sector in the economy market and it should have the ability to manage the information and research, and especially, to innovate based on those. The development of the communities in the future will focus on a combination of productivity and innovation, these being able to practice the connection in all key sectors of the economy. (Hall \& Williams, 2008)

The tourism industry along with other industries has been marked by major changes, due to the development of the internet and mobile telephony, and in generally in data transmission. The innovative strategies have been successfully applied by all stakeholders of the sector, the travel agencies, or non-governmental organizations which activate in the field with the aim of developing tourism in a sustainable direction for host communities.

The tourism has become a remarkable social and economic miracle for everyone. Being carried out by the inclination of every human into new destinations, meetings, experience, in a word desire for discovery and fulfillment. For people with education, as well as for the majority of populations, the tourism, today is a movement of recreation the masses.

Today, individuals from the national and international level, choose new destinations to exit from the daily work and to experience new cultures and adventures. The modern tourist is mainly attracted by the beauty of nature which it contemplates wherever they go and are interested in activities related to the relaxing area, gaming and an experience offered by destinations or by producer organizations, social, economic and politicalreligious communities where the ride. (Hall \& Page, 2014).

Tourism in Romania is an activity linked to the cultural world and natural heritage, as well as the traditions and customs specific to each historical regions of the country. For our country to be attractive, it is vital that all the actors in the tourism sector combine their efforts and work in a consolidated political context. We are more than ever part of a multicultural family that we take in considerations the priorities of the European Union. (European Commission 2020, 2010)

When we talk about tourism as a factor of communities development, we are talking about a tourism destination. Romania needed capabilities to become a tourist destination, competitive and grow in the area of Eastern Europe and not only. This research makes an analysis of the flow of visitors in Romania, but also an analysis of statistical data provided by the National Statistics Institute of Romania (in the range of 2013 - 2016) as regards departures Romanian population abroad. We were interested to see what geographical areas come and visit us, and what means, but especially if this tourist flow analyzed for a period of four years has an impact on the development of the community. Development on which we're going to look at from the perspective of the increase and diversification of accommodation units on the territory of Romania during the period analyzed. Note that a tourist destination to be a competitive must to offer high quality in tourism services, and customer satisfaction produced on the measure. (Caber et al. 2012).

Taking into account of the above, research has focused on the two bearings, one on the analysis of the number of visitors /arrivals in our country through the points of the border, in the period of 2013 - 2016, and the other on the departure number of Romanians outside, during the same period. I've been watching the evolution of the number of persons who have visited the territory of the country and the number of Romanians who went. 
The purpose of the analysis was to identify the number and the origin of foreign tourists, to increase the tourist circulation in the Romanian territory - a factor for creating tourist products in the developing communities. In the same time, we were interested to make a comparison between the number of entries and exits in the country, to find out what was the variation from one year to another.

\section{Literature review}

When we refer to the tourism sector, we are referring to travel, when people are traveling over a short period of time outside their home. This movement, as well as the economic process, requires the satisfaction of must have / services provided by specialized operators on the main activities, such as accommodation, transport, and entertainment. According to Kitchin Rob and Nigel Thrift (2009), tourism can be limited to the following concepts: movement of people - a sector of the economy and a system extended relational interaction between people, including their need to travel outside their communities and services which are trying to meet these needs through tendered products.

The ideal that the tourism industry wishes is that the development of tourism and increasing the flow of tourists should not be made in an abusive manner, but through a sustainable tourism, which gives rise to changes on the community where takes place within acceptable limits and sustainable. The development of the communities through tourism can be achieved by a careful planning, development, and innovation. This development is achievable on the basis of principles that allow tourists to understand that there is a need for harmony with the environment, with the population and the culture of the place, in such a way that the development is made for the profit and not to the loss of the community.
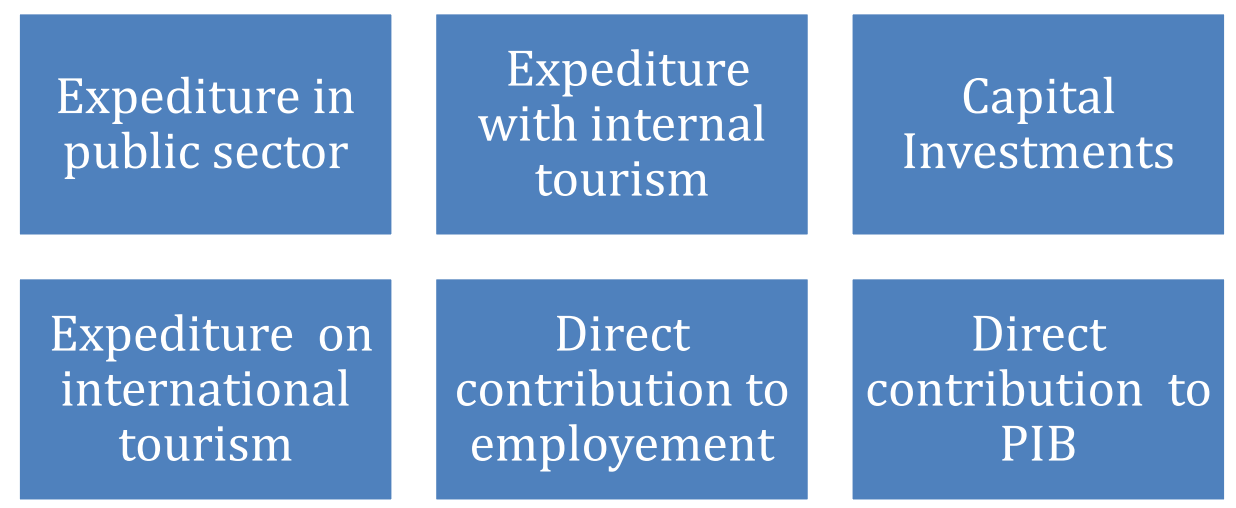

Figure 1. The variables which cause increased tourism

Source: Data taken and processed by authors from by Cárdenas-García, Sánchez-Rivero and Pulido Fernández (2015).

The concept of community development leads us to the concept of economic growth, where Cárdenas-García, Sánchez-Rivero, and Pulido-Fernández (2015) have identified six variables which determine the increase in tourism, shown in Figure 1. These are: expenditure in the public sector, which are public expenditure for individual services that are not linked to the market and of which the beneficiaries can be identified separately; the expenditure of domestic travel, which are the expenditure incurred by resident in their activities tourist attractions while traveling in their own country; the capital investments 
are expenditure on capital goods carried out of all sectors directly involved in the tourism industry and travels. Thus, the capital investment in the tourism industry-specific resources, such as the new accommodation facilities for visitors or acquisition of transport equipment. Expenditure on international tourism is the expenditure incurred by international tourists in the country, both for business trips and for voyages, including the cost of transport; the direct contribution to employment refers to the number of jobs created by the increase in travel, not only in the tourism industry; and the last variable to which the authors refer is the direct contribution to gross domestic product generated by all sectors directly related to tourists, being equivalent to total domestic travel and tourism expenditure in a country, fewer purchases made by these sectors.

On the other hand, the real importance of tourism is not limited to the fact that it contributes to the growth of the economy in general but to the fact that this increase in tourism, in the right circumstances, influences the economic and cultural progress of the community, improving the living standard of the population resident. (Ashley et al. 2007; Dwyer et al. 2004; García, 2005; Hernández et al. 2013; Rosentraub et al. 2009).

The community is the key to stakeholder in the development process, sustain Aref $\mathrm{F}$, Gill SS, Farshid, A. (2010), and her commitment is important, so the authors claim that tourism development should be seen as one of the alternative development strategies, which can help communities overcome socio-economic vulnerabilities, retain their strengths and increase their development chances.

\section{Research methodology}

The scientific approach of the present paper is made from an empirical perspective, so we will use research methods such as observation, synthesis, comparison, statistical analysis, and measurement. Observation will help us to identify the number of visitors arriving in Romania with the main means of transport, as well as the number of Romanians leaving the country. The analysis of the travel/arrivals/departures flows registered at the country borders for a period of 4 years, 2013-2016, is carried out in order to assess the increase of the tourist traffic on the territory of Romania from one year to other. The question we ask is: can tourism be a factor in the development of the visited communities? This touristic process, as well as its results, can cause communities through tourism stakeholders to create competitive tourism products to attract even more tourists. The research aims to make a comparison between the number of entries in the country and that of the exits, to see how they varied from year to year, and what can be deduced from these data.

The data that we analyze from the economic perspective and submit them to the method of comparison, are provided by the National Institute of Statistics of Romania and are public. The data collection was made for a period of 4 years, 2013-2016 and we analyzed variables such as tourist traffic, focusing on arrivals of foreign visitors in Romania by categories of means of transport used by tourists (at the border) and departures of Romanian visitors abroad by the categories of means of transport used (at the border). The categories of means of transport used were the following: road, rail, air, and ship. Unit of measure used: people, thousands of people. The identified and evaluated data are reviewed in Tables 1 and 2. 
Table 1. Arrivals of foreign visitors in Romania by categories of means of transport used by tourists (at the border) during 2013-2016

\begin{tabular}{|c|c|c|c|c|}
\hline \multicolumn{5}{|l|}{$\begin{array}{l}\text { Categories of means of } \\
\text { transport used by tourists }\end{array}$} \\
\hline Years & 2013 & 2014 & 2015 & 2016 \\
\hline $\begin{array}{l}\text { Total / UM - people, } \\
\text { thousands of people }\end{array}$ & 8019 & 8442 & 9331 & 10223 \\
\hline $\begin{array}{c}\text { By means of road } \\
\text { transport }\end{array}$ & 6244 & 6390 & 7475 & 7677 \\
\hline By rail means of transport & 232 & 173 & 143 & 123 \\
\hline By air transport & 1347 & 1690 & 1535 & 2257 \\
\hline By means of shipping & 196 & 189 & 178 & 166 \\
\hline \multicolumn{5}{|c|}{ Source: Data are taken and processed by authors from NATIONAL INSTITUTE OF STATISTICS 19} \\
\hline \multicolumn{5}{|l|}{$\begin{array}{c}\text { Categories of means of } \\
\text { transport used by } \\
\text { tourists }\end{array}$} \\
\hline Years & 2013 & 2014 & 2015 & 2016 \\
\hline $\begin{array}{l}\text { Total / UM - people, } \\
\text { thousands of people }\end{array}$ & 11.364 & 12.299 & 13.118 & 16.128 \\
\hline $\begin{array}{c}\text { By means of road } \\
\text { transport }\end{array}$ & 8794 & 9362 & 10245 & 11101 \\
\hline $\begin{array}{l}\text { By rail means of } \\
\text { transport }\end{array}$ & 187 & 158 & 135 & 96 \\
\hline By air transport & 2360 & 2756 & 2712 & 4906 \\
\hline By means of shipping & 23 & 23 & 26 & 25 \\
\hline
\end{tabular}

Source: data are taken and processed by authors from NATIONAL INSTITUTE OF STATISTICS $1998-2016$.

For the present study, the focus of the analysis is on the statistical data regarding the arrivals of visitors to Romania, mainly on their own. We will also find out how many of those who have arrived, have stayed in accommodation. And in order to identify if there is a correlation between the increase in the number of arrivals with the number of overnights, we will also analyze the increase in the number of accommodation units in Romania during 2013-2016. We consider that the increase of foreign arrivals in the country influences the economic development in the tourism industry from the perspective of providing services: accommodation, meals, transport, entertainment, relaxation, etc.

In table number 3 , we collected data on the origin of the visitors by country and continent and we ranked them according to the number of arrivals. 
Table 3. Arrivals of foreign visitors to Romania from continents and countries of origin during 2013-2016

\begin{tabular}{|c|c|c|c|c|c|}
\hline $\begin{array}{c}\text { Total / number } \\
\text { of people / UM- } \\
\text { (thousands of } \\
\text { people) }\end{array}$ & 8.019 & 8.442 & 9.331 & 10.223 & 36.015 \\
\hline $\begin{array}{l}\text { Continents, } \\
\text { home countries } \\
\text { for foreign } \\
\text { tourists }\end{array}$ & The year 2013 & The year 2014 & $\begin{array}{c}\text { The year } \\
2015\end{array}$ & $\begin{array}{c}\text { The Year } \\
2016\end{array}$ & $\begin{array}{c}\text { Years } \\
2013-2016\end{array}$ \\
\hline Europe & 7526 & 7815 & 8678 & 9508 & 33.527 \\
\hline European Union & 4719 & 4996 & 5346 & 5525 & 20.586 \\
\hline Austria & 200 & 202 & 180 & 142 & 724 \\
\hline Belgium & 48 & 55 & 47 & 65 & 215 \\
\hline Bulgaria & 1136 & 1209 & 1524 & 1527 & 3.869 \\
\hline Cyprus & 7 & 9 & 7 & 12 & 35 \\
\hline Denmark & 12 & 15 & 12 & 20 & 59 \\
\hline Estonia & 5 & 7 & 6 & 6 & 24 \\
\hline France & 136 & 147 & 129 & 201 & 613 \\
\hline Finland & 7 & 7 & 6 & 9 & 29 \\
\hline Germany & 448 & 470 & 438 & 466 & 1.822 \\
\hline Greece & 76 & 72 & 63 & 91 & 302 \\
\hline Ireland & 11 & 17 & 14 & 26 & 68 \\
\hline Italy & 332 & 355 & 324 & 425 & 1.436 \\
\hline Luxembourg & 1 & 2 & 2 & 2 & 7 \\
\hline Latvia & 6 & 6 & 8 & 11 & 31 \\
\hline Lithuania & 10 & 12 & 16 & 19 & 57 \\
\hline Malta & 2 & 3 & 2 & 3 & 10 \\
\hline Netherlands & 71 & 78 & 65 & 89 & 303 \\
\hline Poland & 300 & 308 & 355 & 302 & 1.265 \\
\hline Portugal & 53 & 62 & 46 & 38 & \\
\hline UK & 104 & 140 & 122 & 180 & 546 \\
\hline Czech Republic & 90 & 84 & 85 & 67 & 326 \\
\hline Slovakia & 100 & 97 & 109 & 75 & 381 \\
\hline Slovenia & 23 & 21 & 20 & 14 & 78 \\
\hline Spain & 64 & 76 & 57 & 103 & 300 \\
\hline Sweden & 22 & 25 & 26 & 42 & 115 \\
\hline Hungary & 1443 & 1495 & 1661 & 1562 & 6.161 \\
\hline Croatia & 12 & 22 & 22 & 28 & 84 \\
\hline $\begin{array}{l}\text { The Russian } \\
\text { Federation }\end{array}$ & 176 & 73 & 61 & 68 & 378 \\
\hline Belarus & 143 & 58 & 39 & 54 & 294 \\
\hline Yugoslavia & : & $:$ & $:$ & $:$ & \\
\hline Serbia & 319 & 312 & 352 & 427 & 1.410 \\
\hline Macedonia & 24 & 25 & 28 & 30 & 107 \\
\hline
\end{tabular}

DOI: 10.2478/picbe-2018-0057, pp. 639-650, ISSN 2558-9652| Proceedings of the $12^{\text {th }}$ International Conference on Business Excellence 2018 


\begin{tabular}{|c|c|c|c|c|c|}
\hline Montenegro & 3 & 3 & 3 & 4 & 13 \\
\hline $\begin{array}{l}\text { Republic of } \\
\text { Moldova }\end{array}$ & 995 & 1277 & 1633 & 1918 & 5.823 \\
\hline Turkey & 254 & 255 & 301 & 327 & 1.137 \\
\hline Ukraine & 794 & 716 & 823 & 1055 & 3.388 \\
\hline Africa & 25 & 28 & 31 & 32 & 116 \\
\hline Egypt & 7 & 7 & 7 & 8 & 29 \\
\hline North America & 209 & 294 & 222 & 259 & 984 \\
\hline USA & 142 & 221 & 168 & 176 & 707 \\
\hline Asia & 241 & 285 & 353 & 402 & 1.281 \\
\hline Israel & 95 & 136 & 187 & 230 & 648 \\
\hline $\begin{array}{c}\text { Australia, } \\
\text { Oceania and } \\
\text { other territories }\end{array}$ & 17 & 19 & 20 & 21 & 77 \\
\hline $\begin{array}{c}\text { Countries and } \\
\text { territories not } \\
\text { specified }\end{array}$ & 1 & 1 & 1 & 1 & 4 \\
\hline
\end{tabular}

\section{Results and discussion}

Analyzing the data from the first table, we note that although Romania's road infrastructure suffers from a lack of motorways linking the north with the south or the east with the west, foreign arrivals in our country recorded significant increases year by year and the preferred means of transport to enter the country was the car. In 2013, a total of 6,244,000 visitors arrived, the number of which, according to the table, increased by about a 1.5 million in the four years analyzed, reaching 11,101,000 visitors in 2016. Another preferred means of transport for foreigners is the plane, especially as airlines have increased the number of flights to Romania, especially low-cost flights, from several European destinations and beyond. These have led to an increase in tourist traffic to Romania, from 1,347,000 visitors in 2013 to 2,257,000, increasing over the four years by about one million. It seems that the increase in road arrivals is more significant. We will see that the explanation lies in the origin of the visitors. Arrivals by rail and ship are decreasing in importance, year-on-year they are in the order of hundreds of thousands, so if in 2013 we have 232,000 visitors by train, in the four years analyzed they have dropped to 123,000 visitors. The causes are multiple: the deplorable state of the railway infrastructure in Romania, which lacked investments after the revolution, thus requiring a huge time of crossing the country. The decrease in arrivals to the Black Sea and the Danube respectively fell from 196,000 in 2013 to 166,000 in 2016.

The situation of Romanians' departures abroad by means of transport used at the border differs from arrivals, meaning that the figures clearly show that departures are increasing year by year and comparing the number of arrivals between 2013-2016, ie. $36,015,000$ of foreigners, compared to $52,894,000$ Romanians left abroad. The difference is about 17 million, similar to Romania's population. Low-cost companies offer to make a dent, and there is high inward-outward traffic to neighboring countries, hence the high arrivals and departures figures. Between 2013 and 2016 we have 39,502,000 country-wide departures, compared to 27,786,000 arrivals. This data should ring the alarm to 
stakeholders in the tourism industry, as they need to understand that these departures are money flowing out of the country and industry, to other more performant, competitive and sometimes even cheaper industries in the products offered on the international tourism market.

Continuing the analysis of these statistical data, we focus on the table no. 3, where we have a detailed breakdown of arrivals of foreign visitors in Romania, based on their countries of origin. As we have identified, tourist traffic at the Romanian border, it is much higher through road transport, as most of the visitors are among the land neighbors of the country: Hungary, Ukraine, Moldova, Bulgaria, and Serbia, according to chart 1.

According to data provided by the National Institute of Statistics between 2013 and 2016, most of the foreign visitors arriving in Romania come from Hungary, 6,161,000 people, the second place is Moldovans, a small distance from the Hungarians, 5,823,000 people, with a fantastic increase in 2016, when about 2 million visitors arrived in Romania, almost half the total recorded in the four analyzed years. Bulgarians ranked third with $5,396,000$ thousand arrivals.

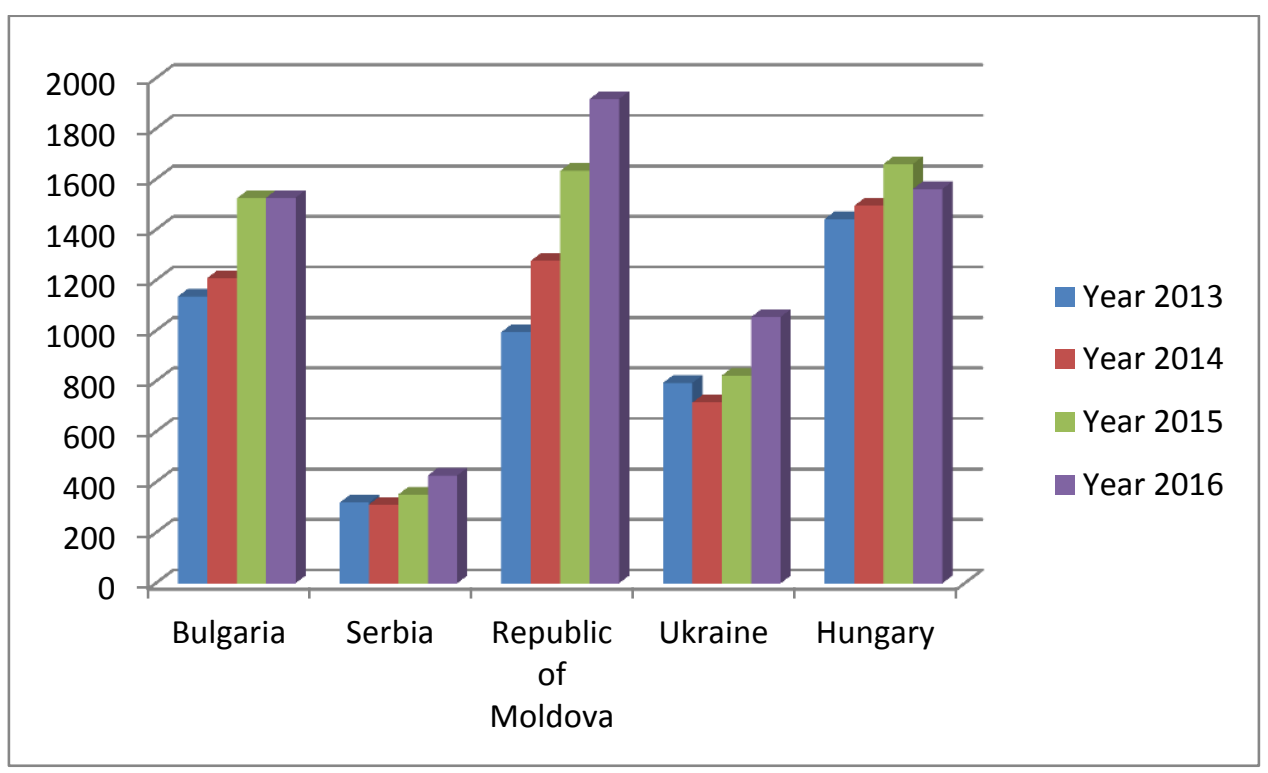

Chart 1. Arrivals of foreign visitors in Romania from neighboring countries during 2013-2016 Source: data are taken and processed by authors from NATIONAL INSTITUTE OF STATISTICS $1998-2016$.

It is worth noticing that the number of arrivals of our neighbors is much higher than that of visitors arriving from Germany 1,822,000 or Italy 1,436,000, countries in which the tourism industry in Romania is orienting its strategy of promoting itself to. A pleasant surprise comes from the Asian continent and we notice that the number of arrivals from this continent in our country is close to a European country, such as Poland. In 2013-2014, we have 1,281,000d Asian visitors in Romania.

Of all foreigners who visit us by various means of transport, only a few of them stay overnight in our country, as for many of them we are just a transit country. Thus, in Chart no 2 we have an analysis of the overnight stays of foreign tourists in the accommodation units, during the period 2013 - 2016. We can distinguish that most of them come from Germany, so of those who arrived 1,822,000,1,012,000 people lodge in Romania, along with other nationalities, 812,000 tourists from Italy and Israel about 700,000 tourists, these are the top 
3 countries in Europe. Close to the top of the list are the United States and the United Kingdom, with about 500,000 tourists accommodated. The statistical analysis of the data shows that out of the 546,000 British tourists in the four years analyzed 500,000 overnight and out of the 707,000 American tourists, a total of 500,000 were guests in accommodation in our country. The year 2016 as seen from the chart brings an increase in overnight stays from tourists from Germany, Israel, and Italy.

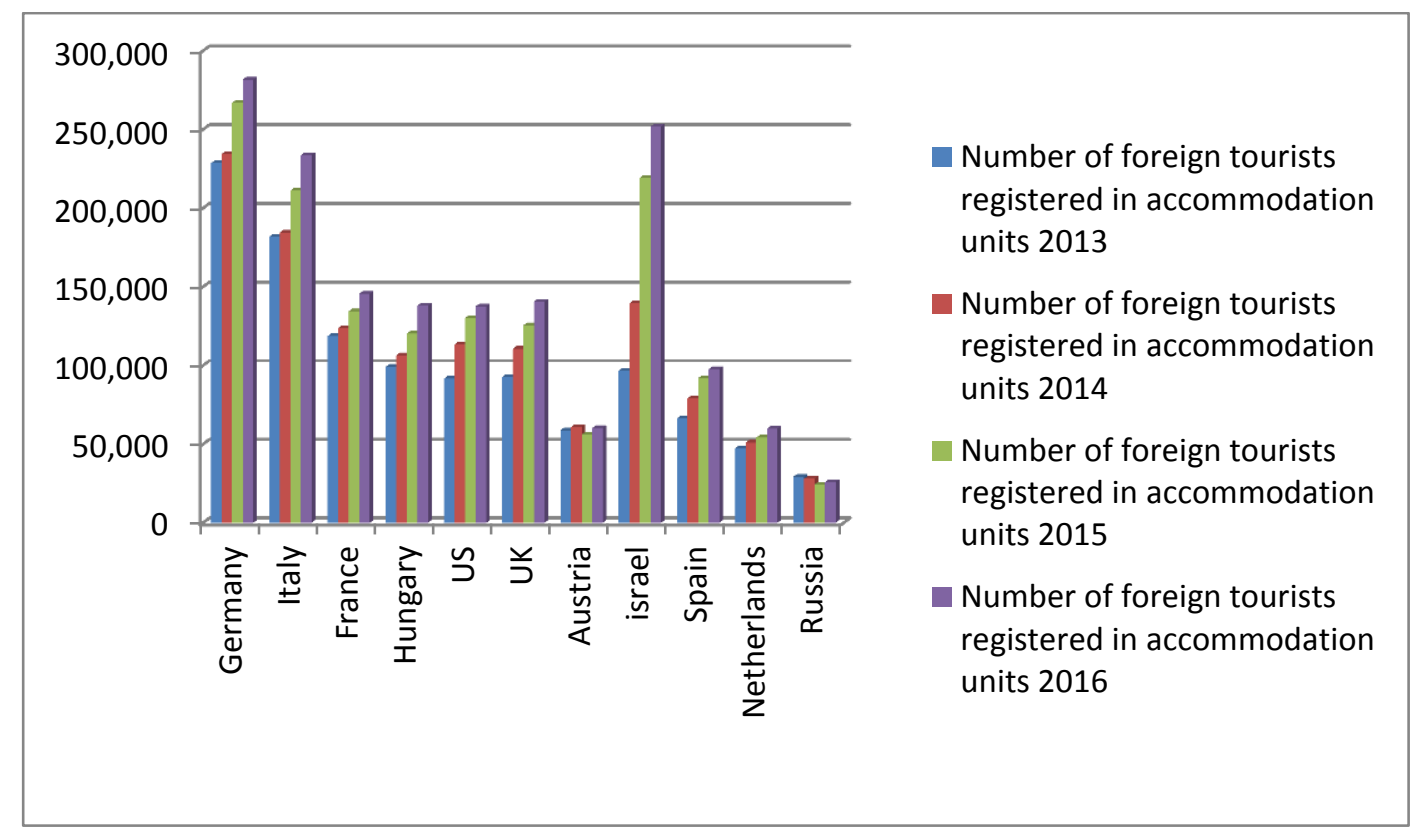

\section{Chart 2. Number of foreign tourists registered in accommodation units in Romania during 2013-2016}

Source: data are taken and processed by authors from NATIONAL INSTITUTE OF STATISTICS 1998 - 2016.

This increase may be due to factors such as the increase in the number of accommodation units in our country, which led to a diversification of the tourist products offer for those interested in visiting our country, but also the purchasing power and the economic and tourist development of destinations in Romania. In chart number 3 we have a breakdown of the tourist reception facilities with functions of tourist accommodation for the period 2013-2016, both private and state-owned. The development of tourism infrastructure in Romania in the private sector continued to grow year by year after the revolution. As can be deduced from chart number 3, agrotourism pensions are ranked first, we have a number of 7,209, followed by 5,970 hotels identified for the period 2013-2016 and third place in the top are tourist pensions with 5,715. This result tells us that the investment power in the Romanian tourism industry is lower because the investments are made on European grants, hence a large number of boarding houses. In order to build a hotel, you need a much larger budget, a strong brand to succeed in attracting foreign tourists. The increase in the number of hotels built compared to 2013 is 85 in 2016, so at 1,445 it reached 1,530 compared to the example of agrotouristic hostels built in 2016 2,208 compared to 1,598 in 2013 . The investment budget is very different, which accounts for the high discrepancy.

The data show that the largest number of arrivals in our country comes from our 
neighbors, so a tourism promotion strategy aimed at the neighboring markets would be an important factor for the development of tourism communities, all the more so with as are the countries whose main industry generating economic profit is tourism.

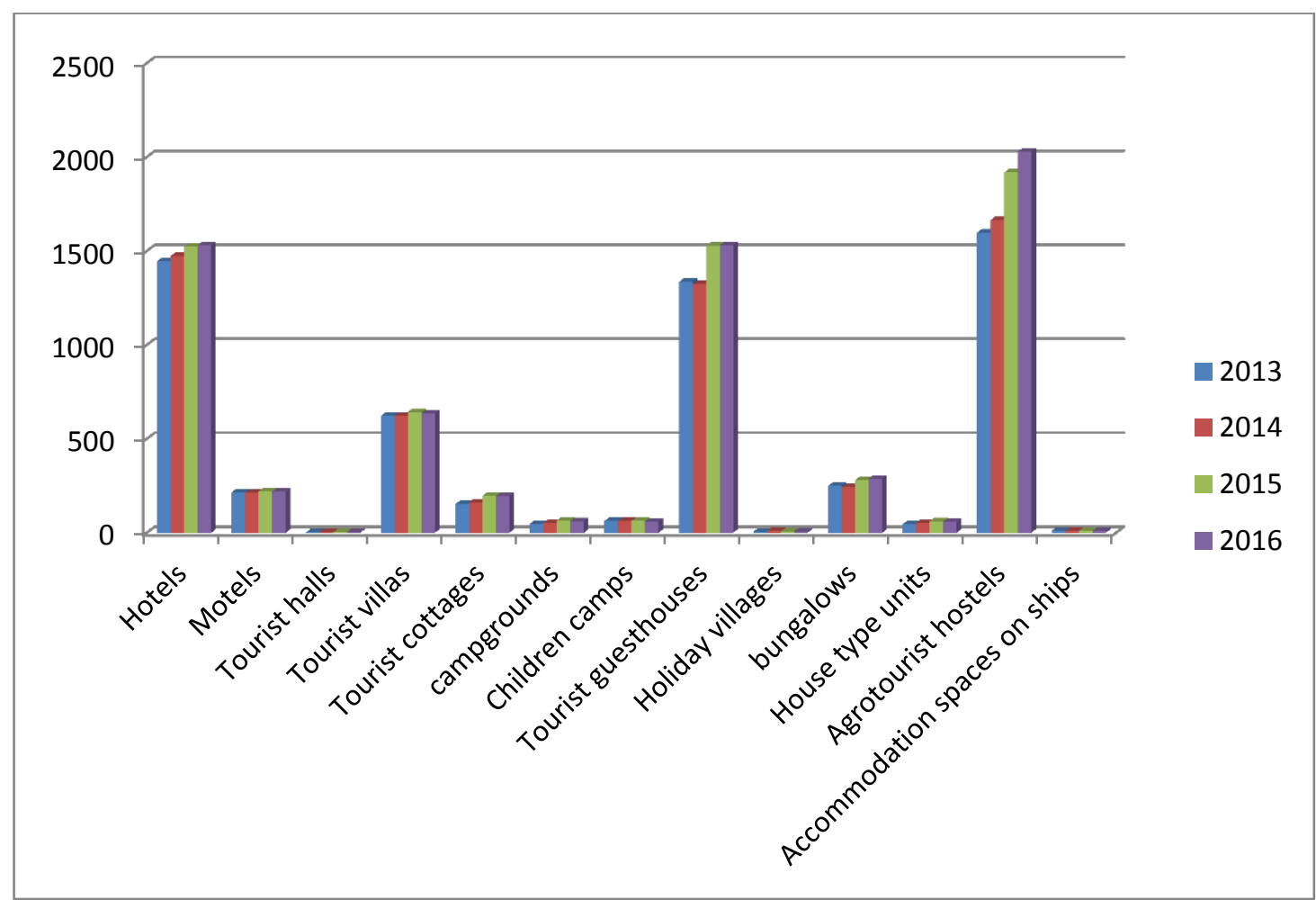

PICBE $\mid 648$

\section{Chart 3. Number of tourist accommodation establishments with tourist accommodation functions in Romania during 2013-2016}

Source: data are taken and processed by authors from NATIONAL INSTITUTE OF STATISTICS $1998-2016$.

\section{Conclusions}

The results of the research show an annual ascendant evolution of the tourist traffic in Romania, which is a positive aspect in a former communist country that was closed and not at all known for the international environment. From this position, Romania has become a sought-after tourist destination at international tourism fairs where local authorities, together with Romanian tourism industry agents, participate and promote different destinations in the country and products tailored to each possible customer. National and local authorities along with tourism industry actors need to be aware of the importance of this industry, according to international organizations dealing with economic development (OECD 2010, WTTC 2010, UNCTAD 2011, UNWTO 2006, UNWTO 2012), highlighting that tourism has certain characteristics that make it an activity that needs to be taken into account when it is in the process of improving the socio-economic conditions of a territory, so that proper management of it results in a number of positive effects in any territory. A long-term national policy of investment and promotion of the destination Romania at international level is necessary, especially since the data obtained clearly tells us that the interest in the Romanian tourism is increasing and this fact leads to the development of the community where it is being developed. 
We appreciate that Romanian tourism will have to be focused, for the future, on developing and providing experience, services, and infrastructure to meet the expectations of potential customers. The community is vital to the visitor experience, studies showing that tourism in a destination can't be sustainable without its input and involvement. At the same time, tourism has a major impact on the community, be it environmental impact or economic, social or cultural impact, which turns the management of visitors' experience into a capital-intensive activity.

We consider that following the upward trend of tourism development in our country, the host communities will contribute to the economic and social development of the tourist interest areas, to the better capitalization of local resources by including them in the structure of national or international tourism consumption.

\section{References}

Aref F, Gill SS, Farshid, A. (2010). Tourism development in local communities: As a community development approach. Journal of American Science, 6, 155 - 161

Ashley, Caroline, Peter de Brine, Amy Lehr, and Hannah Wilde (2007). The Role of the Tourism Sector in Expanding Economic Opportunity. Cambridge: Kennedy School of Government, Harvard University.

Cárdenas-García Pablo Juan, Marcelino Sánchez-Rivero and Juan Ignacio PulidoFernández.(2013): Does tourism growth influence economic development? Journal of Travel Research, 54 (2), 206-221.

Caber Meltem, Tahir Albayrak, and Kurt Matzler. (2012). Classification of the Destination Attributes in the Content of Competitiveness. Jr. of Vac. Mark., 18 (1), 43-56.

Communication from the European Commision 2020, (2010). A strategy for smart, sustainable and inclusive growth, Brussel, accessed January 15, 2018, http://ec.europa.eu/eu2020/pdf/COMPLET\%20EN\%20BARROSO\%20\%20\%20007 \%20-\%20Europe\%202020\%20-\%20EN\%20version.pdf.

Dwyer Larry, Peter Forsyth, and Ray Spurr. (2004). Evaluating Tourism's Economic Effects: New and Old Approaches. Tourism Management, 25 (3): 307-17

García Alfredo. (2005). Turismo y Desarrollo Económico. Un Acercamiento al Caso Cubano. Temas, 43:43-55.

Hall Michael C. And Allan Williams (2008), Tourism and innovation, London, Routledge

Hall Michael C. and Stephen Page J. (2014). The geography of tourism and recreation: Environment, place, and space. London Routledge.

Hernández Rosa M. and Oscar Gonzalez. (2013). Rural Lodging Establishments as Drivers of Rural Development. Journal of Travel Research. DOI: 10.1177/0047287513481273.

National Institute of Statistics 1998-2016, accessed January 7-15, 2018, http://statistici.insse.ro/shop/index.jsp?page=tempo2\&lang=ro\&context=63.

OECD (Organization for Economic Cooperation and Development). (2010). Tourism Trends \& Policies. Paris: OECD.

Kitchin Rob and Thrift Nigel (2009). International encyclopedia of human geography, Publishing house Elsevier, Amsterdam-Boston-London-Paris-Sydney-Tokyo-etc.

Rosentraub Mark S. and Mijin Joo. (2009). Tourism and Economic Development: Which Investments Produce Gains for Regions? Tourism Management, 30 (5), 759-70.

UNCTAD (United Nations Conference on Trade and Development). (2011). Fourth United Nations Conference on Least Developed Countries. Istanbul: UNCTAD. 
UNWTO (United Nations World Tourism Organization). (2006). Poverty Alleviation through Tourism: A Compilation of Good Practices. Madrid: UNWTO.

UNWTO (United Nations World Tourism Organization). (2010). Tourism and the Millennium Development Goals. Madrid: UNWTO.

UNWTO (United Nations World Tourism Organization). (2012). Tourism Highlights. Madrid: UNWTO.

PICBE | 650 